\title{
Pengaruh Metode Mentorship Perawat Terhadap Kemampuan Caring Mahasiswa
}

\author{
Maria Magdalena Setyaningsih ${ }^{1}$, Sr. Felisitas ${ }^{2}$, Maria Prieska Putri P. A ${ }^{3}$ \\ ${ }^{1}$ mmsetyaningsih70@gmail.com, ${ }^{2}$ felis_spu@yahoo.com, ${ }^{3}$ maria_prieska@yahoo.co.id
}

\section{Akademi Keperawatan Panti Waluya Malang \\ pantiwaluyanursing@yahoo.co.id}

\begin{abstract}
Initial study conducted by the researcher on nurse students undertaking clinical practice shows that the nurse students are not yet competent in nursing care. Previous study conducted by Setyaningsih and Sutiyarsih (2015) shows that $47.6 \%$ of nurses have enough ability to guide nurse students. In response to the current facts and phenomena, a method of mentorship may be a breakthrough for the nurse candidates to achieve nursing competence. The purpose of this study is to discover how how mentorship affects nurses in terms of the AKPER X students' capability in nursing care at RS x. This is an experimental study using post test only study design. A sample of 31 students at AKPER X was used by using purposive sampling technique. Data analysis is done through product moment correlation test proceeded with linear regression analysis. Research shows that $100 \%$ of the nurses are able to conduct mentorship, $100 \%$ of the students have caring capability. The result of the product moment correlation test shows that there is positive correlation between the two variables, and the result of linear regression analysis shows the effect of nurse mentorship on students' capability of nursing care. Analysis of the results of the study indicates that the main factor that affects the nurse mentorship is the age, while the main factor that affects students' nursing care ability is age and sex. Based on the study result, researchers suggests that Hospital management improve the mentors' competence in guiding students.
\end{abstract}

Key words : mentorship, nurses, caring capability, students

\section{Pendahuluan}

Salah satu sasaran perawat dalam melaksanakan peran sebagai educator adalah mahasiswa keperawatan. Perawat sebagai seorang perawat pendidik (nurse educator) bertindak sebagai mentor yang memiliki spesifikasi tanggung jawab kepada peserta didiknya yaitu mahasiswa (mentee). Pelaksanaan pemberian edukasi ini didahului dengan adanya hubungan mentorship antara perawat yang berpengalaman dengan mahasiswa (Grossman, 2013). Mentorship diartikan sebagai proses penyampaian pengetahuan, keterampilan dan sikap oleh perawat yang profesional kepada mahasiswa keperawatan (Kinnel dan Hughes, 2010).

Perawat sebagai seorang mentor akan melaksanakan sistem mentorship, karena sistem mentoring memiliki manfaat yang diarahkan pada terwujudnya pencapaian kompetensi mahasiswa keperawatan. Proses mentoring harus melibatkan keaktifan dari dua pihak yaitu mentor dan mentee. Oleh karena itu perawat sebagai mentor harus memiliki keterampilan dan pengetahuan yang tinggi sehingga mahasiswa dapat mencapai standar kompetensinya. Berdasarkan penelitian sebelumnya yang dilakukan oleh Setyaningsih dan Sutiyarsih (2015) menunjukkan bahwa terdapat hubungan yang berbanding lurus antara bimbingan klinik perawat dengan hasil pencapaian keterampilan klinik mahasiswa. Berdasarkan penelitian tersebut disebutkan bahwa $47.6 \%$ perawat dikategorikan dalam bimbingan cukup baik, dan $36.5 \%$ dalam kategori 
bimbingan baik. Dilihat dari sudut pandang pencapaian keterampilan mahasiswa didapatkan hasil sebesar 60.3 $\%$ tidak tercapai, dan $39.7 \%$ mahasiswa tercapai.

Pencapaian target mahasiswa dipengaruhi oleh kompetensi yang dimiliki perawat sebagai mentor. Perawat sebagai seorang mentor harus memiliki beberapa standar kompetensi yang harus dipenuhi yaitu kemampuan kognitif, psikomotor dan afektif (Asmadi, 2008). Sikap caring yang optimal diperlukan dalam mengaplikasikan ketiga kompetensi tersebut sehingga perawat dapat memberikan asuhan keperawatan pada pasien secara profesional .

Mentor sebagai role model bagi mahasiswa menjadi tolok ukur dalam kemampuan caring mahasiswa karena kemampuan caring mentor merupakan bagian dari indikator dalam metode mentorship. Berdasarkan data yang diperoleh melalui studi pendahuluan yang dilakukan tentang pengetahuan tentang bimbingan klinik oleh peneliti menunjukkan terdapat $60 \%$ perawat di RS X memiliki pengetahuan cukup dan $40 \%$ memiliki pengetahuan kurang.

Studi pendahuluan juga dilakukan oleh peneliti pada mahasiswa keperawatan yang sedang menjalani praktik klinik di ruangan juga diperoleh data bahwa mahasiswa belum memiliki kemampuan caring yang optimal terhadap pasien. Ketidakoptimalan ini dapat dibuktikan melalui hasil survei oleh tim manajemen Akper X yang menunjukkan $42,8 \%$ kepala ruang $\mathrm{RS} \mathrm{X}$ menyatakan bahwa kemampuan mahasiswa praktik dalam menerapkan komunikasi termasuk dalam kategori kurang.

Menindaklanjuti fakta dan fenomena yang terjadi diperlukan terobosan baru sebagai perwujudan pencapaian kompetensi perawat masa mendatang. Salah satu terobosan tersebut adalah melalui penerapan metode mentorship. Penerapan metode bimbingan mentorship memiliki manfaat positif bagi profesi keperawatan, RS X melakukan koordinasi dengan AKPER $\mathrm{X}$ untuk mengadakan sebuah pelatihan penerapan mentorship pada Bulan Agustus 2015. Kegiatan pelattihan yang telah dilaksanakan tersebut memberikan penyegaran pengetahuan kepada para mentor dalam melaksanakan kegiatan bimbingan kepada mahasiswa. Hasil akhir dari pelatihan tersebut didapat data bahwa terjadi peningkatan pengetahuan perawat RS X. Peningkatan pengetahuan ini dapat dibuktikan dengan data yang menunjukkan sebesar $45 \%$ perawat memiliki pengetahuan baik. Presentase tingkat pengetahuan ini meningkat dari sebelum dilakukan pelatihan $(0 \%)$ (AKPW, 2015). Pengetahuan yang baik harus dapat diterapkan dalam metode mentorship sebagai metode pembelajaran guna meningkatkan kemampuan caring mahasiswa.

Mentee menjadikan mentor sebagai role model bukan merupakan tindakan yang mudah karena diperlukan sikap untuk dapat mengembangkan critical thinking yang terdiri dari aspek truth seeking (mencari kebenaran), open mindedness (pikiran terbuka), analiticity (kemampuan menganalisa), sistematicity (tindakan sistematis), self confidence (kepercayaan diri), inquistiveness (keingintahuan) (Pai dkk, 2013). Pengembangan sikap oleh mahasiswa memerlukan proses belajar tahap demi tahap. Mahasiswa diharapkan dapat belajar mulai dengan mencintai lingkungan klinik. Penerapan rasa cinta terhadap lingkungan klinik memerlukan sebuah pembinaan oleh mentor yang menjadi role model.

Penelitian ini bertujuan untuk mengetahui pengaruh metode bimbingan mentorship perawat terhadap kemampuan caring mahasiswa Akper $\mathrm{X}$ di $\mathrm{RS} \mathrm{X}$. Penelitian ini memberikan gambaran bagi tim manajemen rumah sakit tentang pengaruh metode mentorship bagi kemampuan caring mahasiswa sehingga mampu memberikan motivasi untuk 
senantiasa memperbaharui manajemen RS dalam rangka pembaharuan SDM.

\section{Metode Penelitian}

Penelitian ini merupakan jenis penelitian kuantitatif eksperimental dengan desain studi post test only. Variabel independen adalah metode mentorship perawat, dan variable dependen yaitu kemampuan caring mahasiswa.

Responden dalam penelitian ini adalah mahasiswa berjumlah 31 mahasiswa dengan teknik pengambilan sampel purposive sampling yaitu pengambilan sampel yang disesuaikan dengan criteria inklusi penelitian, yaitu mahasiswa yang pernah dibimbing oleh mentor minimal 1 kali. Instrumen dalam penelitian yang dilakukan di RS X pada bulan Oktober 2015 ini adalah kuesioner. Data dianalisa secara univariat dengan uraian distribusi frekuensi dan bivariat dengan uji korelasi product moment dan uji regresi linier.

\section{Hasil}

\section{Karakteristik Responden}

\section{Usia Perawat}

Tabel 1 Distribusi Frekuensi Usia Perawat RS X pada Bulan Oktober 2015 $(\mathrm{n}=19)$

\begin{tabular}{lll}
\hline Usia & Frekuensi & Prosentase $(\%)$ \\
\hline$<30$ tahun & 2 & $10.5 \%$ \\
$\geq 30$ tahun & 17 & $89.5 \%$ \\
\hline Total & 19 & $100 \%$ \\
\hline
\end{tabular}

Tabel 1 menunjukkan bahwa sebanyak $89.5 \%$ perawat $(n=19)$ memiliki usia $\geq 30$ tahun .

\section{Tingkat Pendidikan Terakhir Perawat}

Tabel 2 Distribusi Frekuensi Tingkat Pendidikan Terakhir Perawat RS X pada Bulan Oktober 2015 (n=19)

\begin{tabular}{lll}
\hline Usia & Frekuensi & $\begin{array}{l}\text { Prosentase } \\
(\%)\end{array}$ \\
\hline D III & 11 & $57.9 \%$ \\
S1/Ners & 8 & $42.1 \%$ \\
\hline Total & 19 & $100 \%$ \\
\hline
\end{tabular}

Tabel 2 menunjukkan bahwa sebanyak $57.9 \%$ perawat $(\mathrm{n}=19)$ memiliki tingkat pendidikan D III Keperawatan .

3. Jenis Kelamin Mahasiswa

Tabel 3 Distribusi Frekuensi Jenis Kelamin Mahasiswa AKPER X pada Bulan Oktober $2015(\mathrm{n}=31)$

\begin{tabular}{lll}
\hline Jenis Kelamin & Frekuensi & $\begin{array}{l}\text { Prosentase } \\
(\%)\end{array}$ \\
\hline Laki-Laki & 5 & $16.1 \%$ \\
Perempuan & 26 & $83.9 \%$ \\
\hline Total & 31 & $100 \%$ \\
\hline
\end{tabular}

Tabel 3 menunjukkan bahwa sebanyak $83.9 \%$ mahasiswa $\quad(n=31)$ adalah perempuan

\section{Usia Mahasiswa}

Tabel 4 Distribusi Frekuensi Usia Mahasiswa AKPER X pada Bulan Oktober $2015(n=31)$

\begin{tabular}{lll}
\hline Usia & Frekuensi & Prosentase $(\%)$ \\
\hline 20 tahun & 4 & $12.9 \%$ \\
21 tahun & 15 & $48.4 \%$ \\
22 tahun & 7 & $22.6 \%$ \\
23 tahun & 5 & $16.1 \%$ \\
\hline Total & 31 & $100 \%$ \\
\hline
\end{tabular}

Tabel 4 menunjukkan bahwa sebanyak $48.4 \%$ mahasiswa $(n=31)$ berusia 21 tahun; 22,6\% mahasiswa $(\mathrm{n}=31)$ berusia 22 tahun; dan $16,1 \%$ mahasiswa $(n=31)$ berusia 23 tahun. 
Kemampuan Perawat dalam Pelaksanaan Metode Mentorship

1. Frekuensi Perawat Melaksanakan Mentorship

Tabel 5 Distribusi Frekuensi Jumlah Frekuensi Mahasiswa dan Perawat Melaksanakan Mentorship pada Bulan Oktober $2015(n=31)$

\begin{tabular}{lll}
\hline $\begin{array}{l}\text { Jumlah } \\
\text { Frekuensi }\end{array}$ & Frekuensi & $\begin{array}{l}\text { Prosentase } \\
(\%)\end{array}$ \\
\hline $1-3$ kali & 12 & $38.71 \%$ \\
$4-6$ kali & 14 & $45.16 \%$ \\
$>6$ kali & 5 & $16.13 \%$ \\
\hline Total & 31 & $100 \%$ \\
\hline
\end{tabular}

Tabel 5 menunjukkan frekuensi perawat melaksanakan mentorship/ bimbingan kepada mahasiswa. Sebanyak $45.16 \%$ mahasiswa $(n=31)$ melaksanakan kegiatan mentoring sebanyak 4-6 kali dan sebanyak $38.71 \%$ mahasiswa $\quad(n=31)$ melaksanakan kegiatan mentoring sebanyak 1-3 kali.

\section{Kemampuan Perawat dalam} Pelaksanaan Metode Mentorship

Tabel 6 Distribusi Frekuensi Kemampuan Perawat dalam Pelaksanaan Metode Mentorship pada Bulan Oktober $2015(n=19)$

\begin{tabular}{lll}
\hline Kategori & Frekuensi & $\begin{array}{l}\text { Prosentase } \\
(\%)\end{array}$ \\
\hline Mampu & 19 & $100 \%$ \\
$\begin{array}{l}\text { Tidak } \\
\text { Mampu }\end{array}$ & 0 & $0 \%$ \\
\hline Total & 19 & $100 \%$ \\
\hline
\end{tabular}

Tabel 6 menunjukkan bahwa seluruh perawat, yaitu $100 \% \quad(\mathrm{n}=19) \quad$ mampu melaksanakan metode mentorship.

\section{Kemampuan Caring Mahasiswa}

Tabel 7 Distribusi Frekuensi Kemampuan Caring Mahasiswa AKPER X RS X Bulan Oktober $2015(n=31)$

\begin{tabular}{lll}
\hline Kategori & Frekuensi & $\begin{array}{l}\text { Prosentase } \\
(\%)\end{array}$ \\
\hline Kurang & 0 & $0 \%$ \\
Cukup & 0 & $0 \%$ \\
Baik & 31 & $100 \%$ \\
\hline Total & 31 & $100 \%$ \\
\hline
\end{tabular}

Tabel 7 menunjukkan bahwa seluruh mahasiswa, yaitu $100 \%(\mathrm{n}=31)$ memiliki kemampuan caring baik.

\section{Pengaruh Metode Bimbingan Mentorship terhadap Kemampuan Caring Mahasiswa}

1. Hubungan antara Metode Bimbingan Mentorship dengan Kemampuan Caring Mahasiswa

Hubungan antara metode bimbingan mentorship perawat dengan kemampuan caring mahasiswa dapat tergambar pada tabel dibawah ini:

Tabel 8 Uji Korelasi Product Momen antara Metode Bimbingan Mentorship dengan Kemampuan Caring Mahasiswa Bulan Oktober $2015(n=31)$

\begin{tabular}{|l|l|l|}
\hline Keterangan & $\begin{array}{l}\text { Nilai } \\
\text { koefisien } \\
\text { korelasi }\end{array}$ & $\begin{array}{l}\text { Nilai } \\
\text { sig. } \\
(\mathrm{p})\end{array}$ \\
\hline $\begin{array}{l}\text { Hubungan antara Metode } \\
\text { Bimbingan Mentorship } \\
\text { Perawat dengan Kemampuan } \\
\text { Caring Mahasiswa AKPER } \\
\text { X Di RS X }\end{array}$ & 0.367 & 0.021 \\
\hline
\end{tabular}

Tabel 8 menunjukkan bahwa terdapat hubungan yang signifikan secara positif antara metode bimbingan mentorship perawat $(X) \quad\left(\mathrm{R}_{X}=0.367\right.$ dan $\left.\mathrm{p}=0.021\right)$ dengan kemampuan caring mahasiswa Akper X di RS X. Adanya hubungan yang signifikan dan positif tersebut memiliki makna semakin banyak mengikuti metode bimbingan mentorship perawat, maka hal itu akan meningkatkan kemampuan caring mahasiswa AKPER X di RS X.

\section{Pengaruh Metode Bimbingan Mentorship terhadap Kemampuan Caring Mahasiswa \\ Pengaruh metode bimbingan} mentorship perawat dengan kemampuan caring mahasiswa dapat tergambar pada grafik dibawah ini: 
Grafik 1

Pengaruh Metode Mentorship terhadap

Kemampuan Caring Mahasiswa AKPER

X Bulan Oktober $2015(\mathrm{n}=31)$

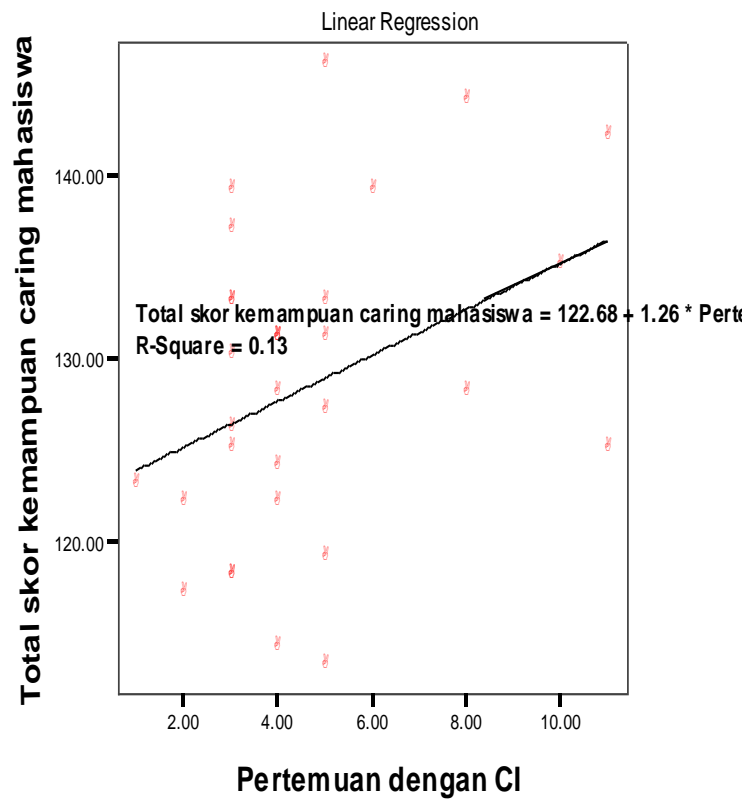

Grafik 1 menggambarkan adanya garis regresi yang mengarah ke kanan atas. Garis tersebut menunjukkan adanya hubungan linearitas antara metode bimbingan mentorship perawat dengan kemampuan caring mahasiswa AKPER X di RS X. Grafik tersebut mengandung arti bahwa semakin lama mengikuti metode bimbingan mentorship perawat dapat mempengaruhi terjadinya peningkatan kemampuan caring mahasiswa AKPER X di RS X.

\section{Pembahasan \\ Kemampuan Melaksanakan Mentorship Perawat}

Tabel 6 menggambarkan bahwa kemampuan seluruh perawat $(\mathrm{n}=19)$ dalam melakukan metode mentorship kepada mahasiswa termasuk dalam kategori baik. Menurut Darmawan (2012). Mentor memiliki beberapa criteria diantaranya adalah memiliki pengetahuan dan keterampilan yang baik serta dapat menjadi decision maker. Kepemilikan keterampilan, pengetahuan dan dapat dijadikan sebagai decision maker tentunya dapat diperoleh berdasarkan banyaknya pengalaman yang diperoleh mentor. Banyaknya pengalaman ini ditentukan oleh berapa lama perawat tersebut berperan sebagai mentor. Hasil penelitian yang diperoleh melalui kuesioner menunjukkan bahwa sebanyak $47.4 \%$ mentor memiliki pengalaman menjadi pembimbing selama $>1$ tahun. Besarnya prosentase tersebut memberikan arti bahwa sebanyak 52.8\% mentor memiliki pengalaman $<1$ tahun. Melihat sebagian dari hasil penelitian yang telah diuraikan tersebut menunjukkan bahwa banyaknya pengalaman sebagai mentor tidak mempengaruhi kemampuannya menjadi mentor karena seluruh perawat pada faktanya "mampu" berperan sebagai mentor yang baik. Fakta ini menyanggah teori yang menyebutkan bahwa salah satu faktor yang mempengaruhi kemampuan menjadi mentorl pembimbing adalah pengalaman (Huber, 2006). Pendapat lain diungkapkan oleh Robin (2001), yang mengungkapkan bahwa masa kerja tidak mempengaruhi kemampuan seseorang dalam produktifitasnya. Fakta tersebut mengandung arti bahwa terdapat faktor lain yang mempengaruhi kemampuan mentor yaitu tingkat pendidikan dan usia.

Faktor pendidikan dan usia seperti dikemukakan oleh Faizin dan Winarsih (2008) dapat mempengaruhi kinerja perawat. Hasil penelitian yang dilakukan oleh peneliti sendiri memberikan fakta yang berbeda seperti yang telah diuraikan pada tabel 2 tentang tingkat pendidikan yang terakhir dicapai oleh perawat mentor. Tabel 2 menggambarkan bahwa sebagian besar perawat (57.9\%) berpendidikan D III dan telah terkategori sebagai mentor yang mampu menerapkan metode mentorship di ruangan. Fakta ini menunjukkan tingkat pendidikan tidak mempengaruhi kemampuan individu memiliki kemampuan yang baik. Seluruh uraian diatas telah menyanggah beberapa teori tentang faktor-faktor yang mempengaruhi kemampuan individu. 
Faktor usia juga mempengaruhi kemampuan individu. Hasil penelitian juga mengungkap tentang usia perawat mentor seperti digambarkan pada tabel 5.1. Tabel 5.1 menunjukkan bahwa sebagian besar perawat mentor, yaitu sebanyak $89.5 \%(n=19)$ berusia lebih dari 30 tahun. Usia 30-45 tahun termasuk dalam usia puncak dewasa awal (Levinson dalam Dariyo, 2004). Usia dewasa awal merupakan usia yang matang dalam psikologis. Seseorang yang berada pada usia dewasa awal akan lebih berorientasi pada tugas dari pada ego pribadi, yang berarti pada usia ini individu memiliki kemampuan bertanggung dalam pekerjaan yang tinggi.

Berdasarkan pembahasan diatas dapat disimpulkan bahwa faktor yang paling mempengaruhi kemampuan perawat sebagai mentor adalah usia.

\section{Kemampuan Caring Mahasiswa}

Caring merupakan bagian inti yang penting terutama dalam praktik keperawatan (Sartika, 2011). Mahasiswa sebagai calon perawat profesional diharapkan mampu memupuk sikap caring dalam proses keperawatan karena caring merupakan jiwa dalam keperawatan. Sikap caring tidak dapat diperoleh secara instan melainkan akan didapatkan secara bertahap dari pengalaman dan berbagai faktor lainnya.

Sebuah penelitian menyebutkan bahwa perawat yang memiliki jenis kelamin perempuan memiliki perilaku caring yang lebih baik daripada perawat berjenis kelamin laki-laki (Suliman, Welmann, Omer \& Thomas, 2009). Hal ini bertolak belakang dengan hasil penelitian oleh peneliti. Berdasarkan hasil penelitian, peneliti menemukan fakta bahwa mahasiswa laki-laki memiliki nilai rata-rata 134 dari total nilai 168, sedangkan mahasiswa perempuan memiliki nilai rata-rata 127 dari total nilai 168. Hal ini menunjukkan bahwa mahasiswa laki-laki memiliki kemampuan caring lebih baik daripada perempuan. Laki-laki dan perempuan memiliki banyak perbedaan khususnya dalam segi psikologisnya. Laki-laki memiliki kemampuan pemecahan masalah yang lebih baik daripada perempuan. Laki-laki juga dapat bersikap lebih tenang dalam menghadapi suatu permasalahan, lebih menggunakan pemikiran daripada emosi dalam melakukan suatu tindakan. Karakter yang dimiliki laki-laki ini mendukung kemampuannya untuk bersikap caring. Salah satu komponen dalam caring sendiri adalah compassion (Kozier \& Barbara, 2007). Compassion adalah kepekaan terhadap kesulitan dan kepedihan orang lain berupa memberikan bantuan kepada orang lain untuk tetap bertahan, memberikan kesempatan untuk berbagi, dan memberikan ruang untuk membagi perasaan dan memberikan dukungan secara penuh. Laki-laki lebih memiliki kemampuan dalam compassion dimana laki-laki tidak berorientasi terhadap perasaan melainkan berorientasi terhadap bagaimana menemukan pemecahan masalah.

Laki-laki berdasarkan penelitian tersebut memiliki kemampuan caring yang lebih baik. Hal ini tidak dapat memberikan tolok ukur yang pasti apabila dibandingkan dengan usia individu dalam menerapkan sikap caring. Hasil penelitian menunjukkan bahwa semakin tinggi usia mahasiswa maka akan semakin tiggi pula kemampuan caring mahasiswa. Hasil penelitian menunjukkan rata-rata nilai tertinggi untuk kemampuan caring dicapai oleh mahasiswa yang berumur 23 tahun yaitu 132.6 dari total 168, sedangkan ratarata nilai terendah dicapai oleh mahasiswa yang berada dalam usia terendah, 20 tahun yaitu 120 dari total nilai 168. Rata-rata nilai tersebut menunjukkan bahwa usia mempengaruhi kemampuan caring mahasiswa. Gambaran hasil penelitian tentang kemampuan caring pada tiap tingkatan usia telah menunjukkan bahwa sikap caring tidak didapatkan secara 
instan dan perlu dipupuk sedini mungkin demi kepuasan pasien sebagai klien.

Cara memupuk sikap caring ini dapat dilakukan dengan terus belajar dari pihakpihak yang mempunyai kemampuan caring yang lebih baik, salah satunya adalah perawat. Perawat dikatakan memiliki kemampuan caring yang lebih baik, sehingga dapat dikatakan perawat sebagai mentor bagi mahasiswa dalam menerapkan sikap caring. Mahasiswa dapat melakukan pembelajaran melalui bimbingan di saat melaksanakan pembelajaran klinik (praktik klinik). Semakin intensif mahasiswa yang bertindak sebagai mentee, maka akan semakin baik pula kemampuannya.

\section{Pengaruh Metode Mentorship Perawat terhadap Kemampuan Caring Mahasiswa}

Penelitian tentang pengaruh metode mentorship perawat terhadap kemampuan caring mahasiswa ini telah menunjukkan hasil yang positif yaitu sehingga didapatkan hasil bahwa terdapat pengaruh metode mentorship perawat terhadap kemampuan caring mahasiswa.

Semakin sering mahasiswa diberikan bimbingan dari mentor, akan semakin meningkat pula kemampuan caring mahasiswa. Perawat sebagai mentor berperan sebagai role model bagi mahasiswa sebagai mentee. Semakin sering mentee melakukan kegiatan mentoring bersama mentor maka mentee secara tidak langsung melakukan proses identifikasi sehingga kemampuan yang dimiliki semakin meningkat secara berkelanjutan. Proses identifikasi yang dilakukan secara berkelanjutan dan positif akan membawa mentee berganti alih menjadi mentor sesuai dengan kemampuan individu masing- masing.

\section{KESIMPULAN \\ Kesimpulan}

Berdasarkan penelitian yang telah dilakukan pada tanggal 9-16 Oktober 2015 dengan responden 31 mahasiswa dan
19 perawat didapatkan hasil sebagai berikut:

1) Seluruh perawat mentor $(n=19)$ di $R S$ $\mathrm{X}$ dikategorikan mampu melaksanakan metode mentorship

2) Seluruh mahasiswa ( $n=31)$ AKPER $X$ memiliki kemampuan caring yang baik

3) Terdapat pengaruh metode mentorship perawat terhadap kemampuan caring mahasiswa AKPER X di RS X

\section{Saran}

Bagi Peneliti, penelitian ini dapat dijadikan sebagai data untuk penelitian selanjutnya tentang pengaruh penerapan sikap caring mahasiswa selama praktik terhadap kepuasan pasien dalam memperoleh layanan.

Bagi Institusi Pelayanan, penelitian ini memberikan motivasi bagi manajemen rumah sakit untuk senantiasa memperbaharui kemampuan perawat sehingga perawat dipertahankan dapat menjadi role model bagi mahasiswa yang merupakan calon teman sejawatnya.

\section{DAFTAR PUSTAKA}

Ali \& Panther. 2008. Profesional Development and The Role of Mentorship. Journal of Nursing Standard. 22(42), 48-56

Asmadi. 2008. Konsep Dasar Keperawatan. Jakarta: EGC

Demir \& Bulut. 2014. Effect of Mentoring Program on Ways of Coping with Stress and Locus of Control for Nursing Students. Korean Nursing Research.pg. 254-260

Dermawan, Deden. 2012. Mentorship dan Preceptorship dalam Keperawatan. Sukoharjo: AKPER Bhakti Mulia

Gangliardi, et all. 2009. Exploring Mentorship as A Strategy to build Capacity for Knowledge Translation Research and Practice: Protocol for 


\section{A Qualitative Study. BioMed Central. 4(55)}

Grossman, Sheila. 2013. Mentoring in Nursing: A Dynamic and Collaborative Proccess. United State: Springer Publishing Company

Hayes, E.F., 2005. Approaches to mentoring: how to mentor and be mentored. Journal of the American Academy of Nurse Practitioners. 17 (11), 442-445.

Hopkins, Susan. 2007. Guidance of Mentors for Nursing Students and Midwives. London: Royal College of Nursing

Hossein, Moonaghi, et all. 2010. Teaching Style in Clinical Nursing Education: A Qualitative Study of Iranian Nursing Teachers' Experiences. Nurse Education in Practice. 10, 812.

Kalaburut, Altas \& Alemdar. 2015. The Relationship Of Clinical Learning Environment To Nursing Students' Academic Motivation. Kontakt. 17(1), e6-e12

Kaur, Sambasivan \& Kumar. 2015. Effect Of Spiritual Intelligence, Emotional Intelligence, Psychological Ownership And Burnout On Caring Behaviour Of Nurses: A CrossSectional Study. Applied Nursing Research. 22(21-22), 3192-3202

Kinnel, David \& Hughes. 2010. Mentoring Nursing and Healthcare Student. London: SAGE Publication Ltd.

Nurmalia, Devi. 2012. Pengaruh Program Mentoring Keperawatan terhadap Penerapan Budaya Keselamatan Pasien di Ruang Rawat Inap RS Islam Sultan Agung Semarang.
Tesis. Tidak Diterbitkan.

Universitas Indonesia

Pai, Eng \& Ko. 2013. Effect of Caring Behavior on Disposition Toward Critical Thinking of Nursing Students. Journal of Professional Nursing. 29(6), 423-429

Parello, Sarconi, Samms \& Boyd. 2013. Developing A Center For Nursing Research: An Influence On Nursing Education And Research Through Mentorship. Nurse Education in Practice. 13, 106-112

Potter \& Perry. 2005. Buku Ajar Fundamental Keperawatan: Konsep, Proses dan Praktik Edisi 4. Alih bahasa, Yasmin; editor Devi Y \& Monica Ester. Jakarta: EGC

Setyaningsih \& Sutiyarsih. 2015. Corellation Clinical Guidances Competence With Clinical Skill Attainment Of Candidate Nursing Students. Complementary Nursing Issues and Updates in 2015. 1,49

Simamora, Roymond H. 2009. Buku Ajar Pendidikan dalam Keperawatan. Jakarta: EGC

Specht. 2013. Mentoring Relationships and The Levels of Role Conflict and Role Ambiguity Experienced by Novice Nursing Faculty. Journal of Professional Nursing. 29(5), e25e31

Werdati (2007). Implementasi program mentorship pada pendidikan keperawatan. Disampaikan pada Pelatihan Nasional Preceptorship dan Mentorship untuk Pendidikan Ners. Yogyakarta, 12 - 14 Februari 2007.

Wojnar, D. M. (2006). Kristen Swanson: Theory of caring. In A. M. Tomey, \& M. R. Alligood (Eds.). Nursing theorists and their work (6th ed.) St. Louis, MO: Mosby 